\title{
Long Memory, Economic Policy Uncertainty and Forecasting US Inflation: A Bayesian VARFIMA Approach*
}

\author{
Mehmet Balcilar* Rangan Gupta ${ }^{\star} \quad$ Charl Jooste^
}

\begin{abstract}
We compare inflation forecasts of a vector fractionally integrated autoregressive moving average (VARFIMA) model against standard forecasting models. U.S. inflation forecasts improve when controlling for persistence and economic policy uncertainty (EPU). Importantly, the VARFIMA model, comprising of inflation and EPU, outperforms commonly used inflation forecast models.
\end{abstract}

JEL CLASSIFICATIONS: C53, E37

KEYWORDS: Inflation, long-range dependency, economic policy uncertainty

\section{Introduction}

Inflation forecasts are important central bank outputs. The Federal Reserve of the United States (U.S.) produce regular inflation forecasts at various forecast horizons. From a theoretical perspective, Faust and Wright (2013) assert that the non-neutrality of monetary policy in the New-Keynesian framework has led to the importance of inflation forecasting from a policy perspective.

Many methodologies have been applied in forecasting U.S. inflation. For an excellent summary of models see Stock and Watson (2009), which compares the forecasting performance of various Phillips curve specifications, and also Faust and Wright (2013) for the performance comparison of newer methods. These methodologies range from simple linear models to large data-driven econometric models and from structural models to nonlinear specifications.

From an univariate perspective, there is widespread evidence that the US inflation rate can be best captured by a long-memory process (Barros and Gil-Alana, 2013; Caporin and Gupta, forthcoming). Interestingly however, the literature on U.S. inflation forecast comparisons either assume inflation to be I(1) or I(0) and then modeled as such (Lovcha and Perez-Laborda, 2013). Also inflation forecasting models that do not directly control for policy uncertainty are often misspecified, given the recent evidence that economic policy uncertainty affects in-sample behaviour of inflation (Colombo, 2013; Jones and Olson, 2013).

\footnotetext{
* We would like to thank two anonymous referees for many helpful comments. However, any remaining errors are solely ours.

* Department of Economics, Eastern Mediterranean University, Famagusta, Northern Cyprus , via Mersin 10, Turkey; Department of Economics, University of Pretoria, Pretoria, 0002, South Africa. Email: mehmet@mbalcilar.net.

- Corresponding author. Department of Economics, University of Pretoria, Pretoria, 0002, South Africa. Email: rangan.gupta@up.ac.za.

- Department of Economics, University of Pretoria, Pretoria, 0002, South Africa. Email: Jooste.Charl@yahoo.co.za.
} 
We address these shortcomings in a Bayesian vector autoregressive fractionally integrated (VARFIMA) model. A VARFIMA model captures the persistence of inflation. The forecasts are conditioned on an uncertainty variable by Baker et al. (2013) to model inflation. Conditioning inflation forecasts on policy uncertainty (EPU) would capture the inflation or deflation effects of uncertainty. We argue that there exists a link between economic uncertainty and inflation. Specifically, the data generating properties of inflation (persistence and volatility) is related to movements in economic policy uncertainty. If a Central Bank targets inflation using interest rates, high policy uncertainty can affect household and firm decisions. As an example, if there is uncertainty about a looming interest rate increase consumers might discount a future hike and cut back on spending and hence inflation moves before any policy decision has been made. For a theoretical overview see Mumtaz and Zanetti (2013) and Bloom (2009). In Bloom (2009) policy uncertainty leads to inaction by firms whereas in Mumtaz and Zanetti (2013) uncertainty affects expected consumption due to Jensen's inequality.

The forecasts are recursive over an out-of-sample period, the starting point of which is determined by tests of structural breaks, and would thus account for time-varying correlation with policy uncertainty. Finally we use the Diebold Mariano (1995) test to compare forecasts from alternative forecasting models.

\section{Data and Methodology}

We use monthly U.S. consumer price inflation data, obtained from the FRED database of the St. Louis Federal Reserve, and the uncertainty index of Baker et al. (2013), obtained from www.policyuncertainty.com, with our period covering January 1985 to June 2014. This gives us a matrix of two time series with a total of 354 observations. In brief, the uncertainty index is derived from three data sources: (i) 10 news paper sources that discuss policy uncertainty, (ii) federal tax code provisions set to expire from the CBO and (iii) disagreement among forecasters from the Survey of Professional Forecasters. An index is then created from the three sources.

To model the long and short range dependence of variables, as well the interdependency between inflation and uncertainty we propose the following $\operatorname{VARFIMA}(p, d, q)$ model:

$\phi(L) D(L)\left[\tilde{x}_{t}-\tilde{\mu}\right]=\theta(L) \varepsilon_{t}$

where $\tilde{x}_{t}$ is a vector of Gaussian time series, $\phi(L)=I-\phi_{1} L-\cdots-\phi_{p} L^{p}$ and $\theta(L)=I-\theta_{1} L-$ $\cdots-\theta_{p} L^{p}$ are matrix lag polynomials for the AR and MA coefficient matrices $\phi_{i}, i=1, \ldots, p$, and $\theta_{i}$, $i=1, \ldots, q$, respectively. $\tilde{\mu}$ is the vector of the means of the time series and $D(L)$ is a diagonoal $k \times k$ matrix that contains the order of fractional integration of $k$ time series: $D(L)=$ $\operatorname{diag}\left[(1-L)^{d_{k}}, \ldots,(1-L)^{d_{k}}\right] \cdot d_{i}$ is the degree of fractional integration of the $i$ th variable and we define $\tilde{d}$ as the vector containing $d_{i}$ for $i=1,2, \ldots, k$. We assume that the errors $\left(\varepsilon_{t}\right)$ are i.i.d. with $\varepsilon_{t} \sim M V(0, \Sigma)$. It is assumed that the roots of $\phi(L)$ and $\theta(L)$ lie outside the unit circle. Furthermore the process is stationary if $-1 / 2<d_{i}<1 / 2, i=1,2, \ldots, k$. If any $d_{i}>1 / 2$ the process is not covariance stationary, but still mean reverting - it takes a long time for mean reversion. Finally, the $D(L)$ operator is defined by a binomial series (for more details see Hassler, 1994). We estimate the model using Monte Carlo Markov Chains in a Bayesian setup following Ravishanker and Ray (2002) to avoid possible over-fitting. This allows us to incorporate prior information and derive a posterior distribution that can be summarized. We use a uniform prior for $\phi(L), \theta(L)$ and $\tilde{d}$, respectively and an improper prior for $\tilde{\mu}$. We assume 
that $\Sigma_{i i}=\sigma_{i}^{2}$ and $\Sigma_{i j}=\rho \sigma_{i}^{2} \sigma_{j}^{2}$, where $\rho$ (measuring contemporaneous correlation) is assumed to have a uniform prior on $(-1,1)$.

We compare the forecasting performance of the $\operatorname{VARFIMA}(p, d, q)$ against a group of competing models using a weighted squared forecast error specification (see van Dijk and Franses, 2003). The weighted squared forecast error specification entails assigning heavy weights on extreme events in the forecast loss function. Essentially this test provides an additional comparison of multiple forecasting models over extreme events in addition to the standard MSFE evaluation. We use the Diebold and Mariano (1995) test modified by Harvey et al. (1997) to compare the statistical significance between the competing models. ${ }^{1}$ These alternative models include a random walk (RW), an $\operatorname{ARIMA}(2,0,0), \operatorname{VAR}(2)$, and $\operatorname{ARFIMA}(2, d, 0)$, with all models selected by the AIC. ${ }^{2}$

It is worth noting, at least conceptually, the differences between the models and specifically what differentiates the VARFIMA from its competitors. In the case where long range dependence is not an issue, but only if the data generating properties of a variable is stationary or non-stationary, than the RW, ARIMA and VAR models are suited to fit the data. These models make explicit assumptions about the data generating properties. In particular, if standard tests suggest that a series is stationary, then any movement in that variable away from its unconditional mean will only be determined by the AR coefficients and the reversion tends to be quick. For some series the data is a near unit root process. Standard test might make a type 1 error and reject the null of stationarity when the data is in fact simply a near unit root process i.e. it takes a long time for the variable to revert back to its unconditional mean. The VARFIMA model controls for the possibility of a near unit root, but now its distribution is conditional on that of other variables - or in this paper's case policy uncertainty. In such cases, Bayesian framework of the long memory models offers three advantages: (1) it incorporates subjective information and stationarity or zero restrictions on parameters, through appropriate prior specifications. (2) it provides the exact finite sample distribution for the fractional differencing parameter, and (3) it controls for model uncertainty. Particularly for the prediction purposes, it allows us to average over the entire distribution of the fractional differencing parameter rather than using just one model. This is important since unit root models (a first-differenced VAR model) are usually favoured by the data. Unit root and long-memory models have rather different consequences for the persistence in the data and incorporating this model uncertainty is instrumental for prediction purposes.

Our out-of-sample forecast starts from Sep 2005, given that the Bai and Perron (2003) tests of multiple structural breaks detected the first break on that date, based on the inflation equation in the $\operatorname{VAR}(2)$. We compare 1, 3, 6 and 12 quarters-ahead forecasts. Forecasts from the

\footnotetext{
${ }^{1}$ Ashley (1998) uses an alternative technique that relies on post sampling techniques to select models. While this technique has many advantages and discusses the pitfalls of overtly relying on small MSE values to discriminate against models, it is computationally more costly and hence we rely on Van Dijk and Franses (2003). Other tests also exist - Makridakis and and Hibbon (2000) use a battery of tests on micro, macro and financial data to distinguish the forecasting accuracy of competing models - in general, complex methods do not necessarily outperform simpler methods.

${ }^{2}$ Multiple information criteria show that the results do not change. The results are available from the authors upon request.
} 
VARFIMA are obtained using predictive densities. The point forecasts for comparison are taken from the medians. ${ }^{3}$ The weighted loss function is specified as:

$L_{i, t}^{w}=w_{t} e_{i, t}^{2}$

Weight $\left(w_{t}\right)$ is then defined as (see Van Dijk and Franses (2003) and Aye et al. (2015) for further details):

- $\quad w_{\text {left }, t}=1-F\left(y_{t}\right) \cdot F\left(y_{t}\right)$ is the cumulative distribution of $y_{t}$ (i.e. inflation) that impose heavier weights the left tail of the distribution (i.e. low inflation periods).

- $w_{\text {right }, t}=F\left(y_{t}\right)$. Imposes heavier weights the right tail of the distribution (i.e. high inflation periods).

- $w_{\text {tail }, t}=1-F\left(y_{t}\right) / \max \left(F\left(y_{t}\right)\right)$. Impose heavier weights on both tails of the distribution.

- If $w_{t}=1$, then the loss function reduces to the standard loss function.

The weighted MSFE is specified as:

$M S F E_{i}=\frac{1}{P} \sum_{t=T+1}^{T+P} w_{t} e_{i, t}^{2}$

where $T+1$ is the start of the forecast and $T+P$ is then end of the forecast. The forecasting performance of model $i$ versus the baseline model 0 is established by calculating the difference between the various loss functions averaged out over the forecast horizon:

$\frac{1}{P} \sum_{t=T+1}^{T+P} d_{i, t}=\frac{1}{P} \sum_{t=T+1}^{T+P} w_{t} e_{0, t}^{2}-\frac{1}{P} \sum_{t=T+1}^{T+P} w_{t} e_{i, t}^{2}$

Figure 1 provides a motivating factor for using the weighted squared forecast error evaluation. The distribution of inflation is asymmetric with large weights on the tails.

3 See Ravishanker and Ray (2002) for more details. 
Figure 1: Inflation density plot and weights for DM test
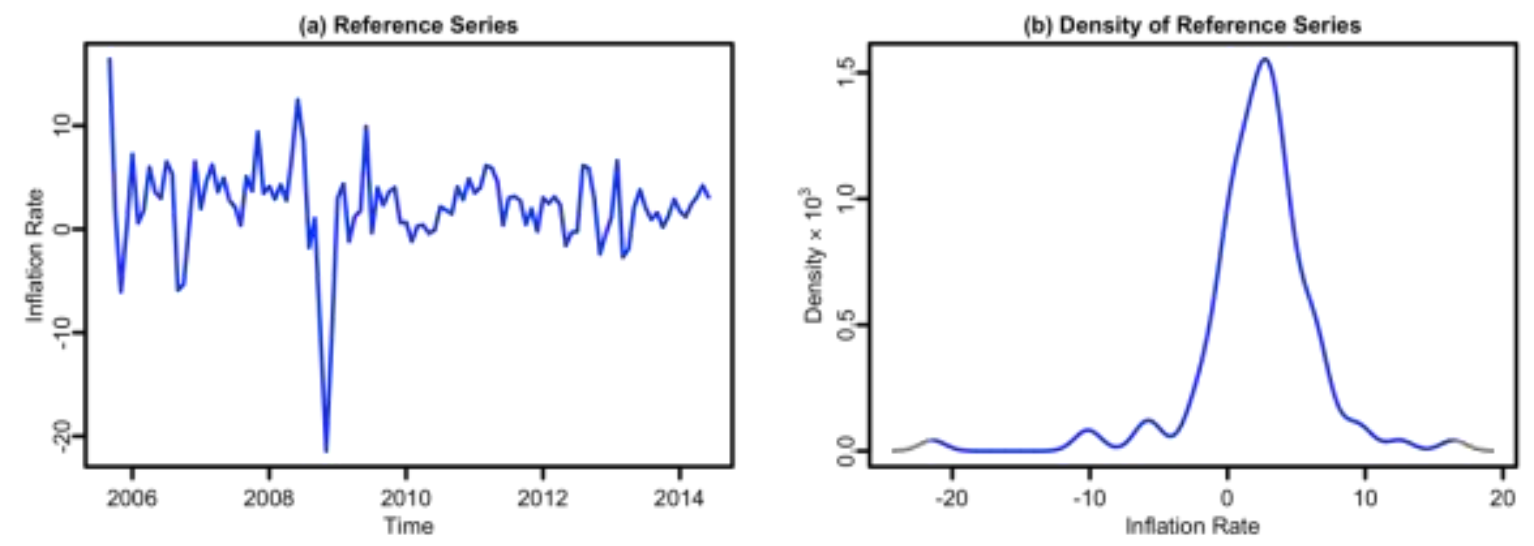

(c) Weights for the High Inflation Periods
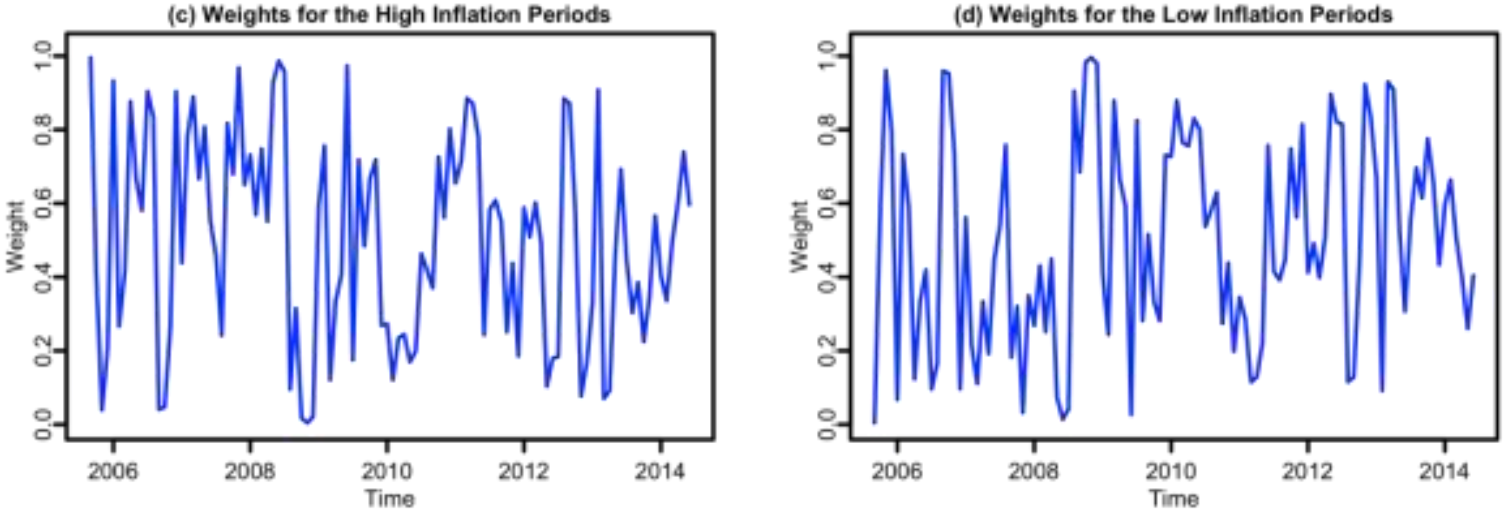

(e) Tail Weights

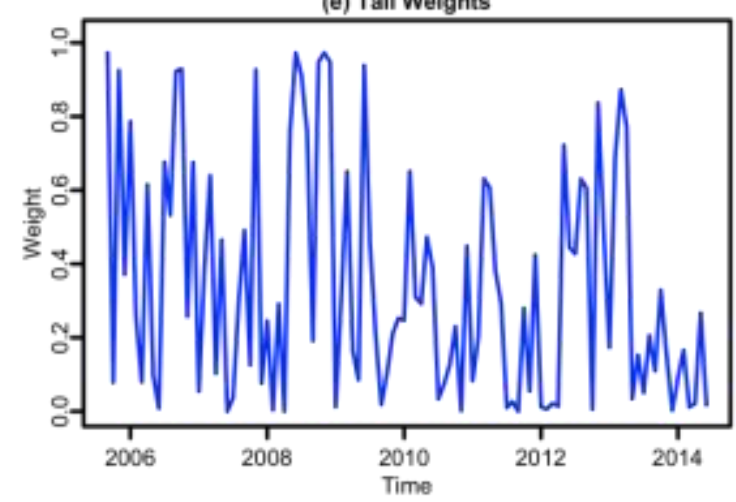

\section{Results}

The differencing parameter for inflation and EPU over the forecast period is presented in Figure 2. It is worth noting that both inflation and EPU are characterized as stationary variables and that the degree of integration for EPU and inflation has been stable. The differencing parameter for inflation, however, is smaller since the financial crisis in 2008/09 - suggesting that persistence in inflation becomes less of a concern during tepid economic growth. 
Figure 2: Estimates of the fractional integration order over the forecasting period 2005:8 - 2014:6

(a) Estimates of $d$ for the inflation series

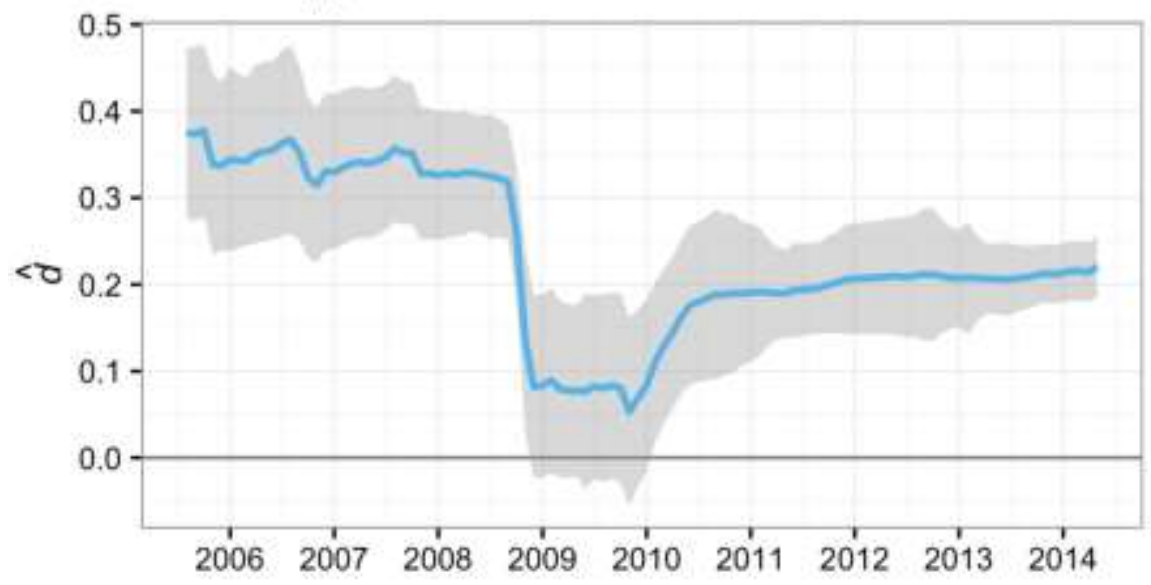

(b) Estimates of $d$ for the EPU series

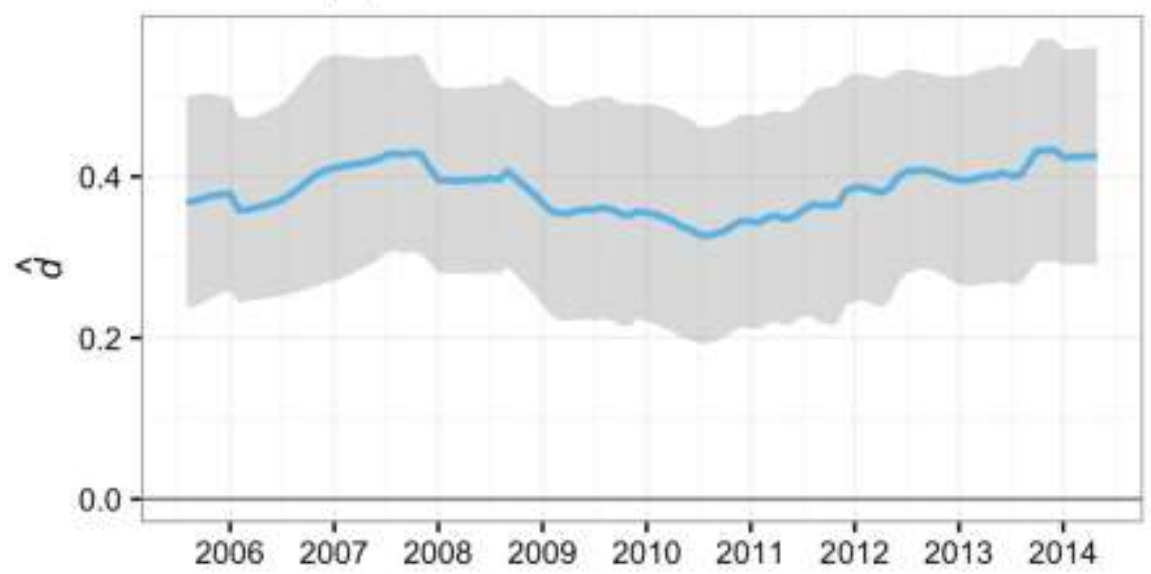

Note: Shaded regions mark the $95 \%$ confidence interval for the estimates of the fractional integration order $d$.

Table 1 compares the root mean squared errors (RMSE) for 12 forecast horizons. The VARFIMA model has the lowest RMSE in the majority of the forecast horizons and performs well for short and longer forecast periods. It never did worse than second place in instances where it had a slightly higher RMSE than an alternative model. 
Table 1: RMSE's

\begin{tabular}{rrrrrr|l}
\hline $\mathbf{h}$ & $\mathbf{R W}$ & ARMA & VAR & ARFIMA & VARFIMA & BEST MODEL \\
\hline $\mathbf{1}$ & 4.5384 & 3.9007 & 3.7744 & 3.9266 & 3.8247 & VAR \\
$\mathbf{2}$ & 6.0297 & 4.2906 & 4.1611 & 4.1004 & 4.0601 & VARFIMA \\
$\mathbf{3}$ & 6.3003 & 4.2925 & 4.2847 & 4.0846 & 4.1031 & ARFIMA \\
$\mathbf{4}$ & 6.0488 & 4.2222 & 4.2008 & 4.0324 & 4.0292 & VARFIMA \\
$\mathbf{5}$ & 6.5500 & 4.2188 & 4.2063 & 4.0330 & 4.0314 & VARFIMA \\
$\mathbf{6}$ & 6.5417 & 4.2052 & 4.1981 & 3.9977 & 3.9993 & ARFIMA \\
$\mathbf{7}$ & 6.2752 & 4.2127 & 4.2103 & 4.0020 & 4.0030 & ARFIMA \\
$\mathbf{8}$ & 6.3384 & 4.2306 & 4.2259 & 4.0180 & 4.0178 & VARFIMA \\
$\mathbf{9}$ & 6.3523 & 4.2408 & 4.2183 & 4.0250 & 4.0231 & VARFIMA \\
$\mathbf{1 0}$ & 6.1880 & 4.2613 & 4.2349 & 4.0449 & 4.0424 & VARFIMA \\
$\mathbf{1 1}$ & 6.1585 & 4.2832 & 4.2630 & 4.0654 & 4.0628 & VARFIMA \\
$\mathbf{1 2}$ & 6.8185 & 4.2926 & 4.2821 & 4.0729 & 4.0710 & VARFIMA \\
$\mathbf{A v e r a g e}$ & 6.1783 & 4.2209 & 4.1883 & 4.0336 & 4.0223 & VARFIMA \\
\hline
\end{tabular}

Tables 2 - 5 summarize the modified DM test for $\mathrm{h}=1,3,6,9,12$ for uniform, boom, bust and tail weights. The tables report standard errors in parenthesis. We include scores to emphasize which row models outperform column models significantly. Positive values indicate that the row model outperforms the column model, while negative values indicate the converse.

None of the models significantly outperform each other for $h=1$ apart from beating the RW model. The RW model is significantly outperformed by the VAR and ARFIMA models. In fact, the RW model is outperformed by all other model specifications using the DM test for $h>1$. The various models seem to perform equally well using the DM test, except for $h=3$ where the VARFIMA model statistically outperforms the ARIMA and VAR models. Note that none of the models significantly outperformed the VARFIMA model - Table 6 supports these results.

The DM test with boom weights also shows that the VARFIMA model has a lower forecast error compared to the other models. This is followed by the ARMA model that is also not bettered by any of the other models. The RW model again performs the worst, preceded by the VAR and then ARFIMA models.

The VARFIMA model beats most of the models also in the DM test adjusted for recession weights. Interestingly the VAR model is a close second at forecasting compared to a poor forecasting performance with boom weights. The VAR model is followed by the ARFIMA, ARMA and RW model.

The ARFIMA and VARFIMA do equally well in the DM test adjusted for tail weights. The RW model is significantly outperformed by other models at each forecast horizon.

The advantage of using a VARFIMA model compared to other forecasting models stems from its ability to produce better forecasts. This is most likely the result of controlling for the persistence in inflation and exploiting the additional information provided by the policy uncertainty variable. One might ask what the marginal benefit of a VARFIMA model over the 
Table 2: Diebold-Mariano Tests with Uniform Weighted Forecast Errors

\begin{tabular}{|c|c|c|c|c|c|c|c|}
\hline & RW & ARMA & VAR & ARFIMA & VARFIMA & plus & minus \\
\hline & & & $h=1$ & & & & \\
\hline RW & & $\begin{array}{c}-1.59 \\
(0.11)\end{array}$ & $\begin{array}{l}-2.14 \\
(0.03)\end{array}$ & $\begin{array}{l}-1.84 \\
(0.07)\end{array}$ & $\begin{array}{l}-1.39 \\
(0.17)\end{array}$ & 0 & 2 \\
\hline ARMA & $\begin{array}{c}1.59 \\
(0.11)\end{array}$ & & $\begin{array}{l}-0.34 \\
(0.74)\end{array}$ & $\begin{array}{c}-0.37 \\
(0.71)\end{array}$ & $\begin{array}{c}0.78 \\
(0.43)\end{array}$ & 0 & 0 \\
\hline VAR & $\begin{array}{c}2.14 \\
(0.03)\end{array}$ & $\begin{array}{c}0.34 \\
(0.74)\end{array}$ & & $\begin{array}{l}-0.07 \\
(0.94)\end{array}$ & $\begin{array}{c}0.43 \\
(0.66)\end{array}$ & 1 & 0 \\
\hline ARFIMA & $\begin{array}{c}1.84 \\
(0.07)\end{array}$ & $\begin{array}{c}0.37 \\
(0.71)\end{array}$ & $\begin{array}{c}0.07 \\
(0.94)\end{array}$ & & $\begin{array}{c}0.47 \\
(0.64)\end{array}$ & 1 & 0 \\
\hline \multirow[t]{2}{*}{ VARFIMA } & $\begin{array}{c}1.39 \\
(0.17)\end{array}$ & $\begin{array}{c}-0.78 \\
(0.43)\end{array}$ & $\begin{array}{l}-0.43 \\
(0.66)\end{array}$ & $\begin{array}{l}-0.47 \\
(0.64)\end{array}$ & & 0 & 0 \\
\hline & & & $h=3$ & & & & \\
\hline RW & & $\begin{array}{c}-2.28 \\
(0.02)\end{array}$ & $\begin{array}{l}-2.22 \\
(0.03)\end{array}$ & $\begin{array}{l}-2.32 \\
(0.02)\end{array}$ & $\begin{array}{l}-2.34 \\
(0.02)\end{array}$ & 0 & 4 \\
\hline ARMA & $\begin{array}{c}2.28 \\
(0.02)\end{array}$ & & $\begin{array}{c}0.33 \\
(0.74)\end{array}$ & $\begin{array}{l}-1.53 \\
(0.13)\end{array}$ & $\begin{array}{l}-1.70 \\
(0.09)\end{array}$ & 1 & 1 \\
\hline VAR & $\begin{array}{c}2.22 \\
(0.03)\end{array}$ & $\begin{array}{c}-0.33 \\
(0.74)\end{array}$ & & $\begin{array}{l}-2.44 \\
(0.01)\end{array}$ & $\begin{array}{l}-2.59 \\
(0.01)\end{array}$ & 1 & 2 \\
\hline ARFIMA & $\begin{array}{c}2.32 \\
(0.02)\end{array}$ & $\begin{array}{c}1.53 \\
(0.13)\end{array}$ & $\begin{array}{c}2.44 \\
(0.01)\end{array}$ & & $\begin{array}{l}-1.42 \\
(0.16)\end{array}$ & 2 & 0 \\
\hline \multirow[t]{2}{*}{ VARFIMA } & $\begin{array}{c}2.34 \\
(0.02)\end{array}$ & $\begin{array}{c}1.70 \\
(0.09)\end{array}$ & $\begin{array}{c}2.59 \\
(0.01)\end{array}$ & $\begin{array}{c}1.42 \\
(0.16)\end{array}$ & & 3 & 0 \\
\hline & & & $h=6$ & & & & \\
\hline RW & & $\begin{array}{c}-1.94 \\
(0.05)\end{array}$ & $\begin{array}{l}-1.94 \\
(0.05)\end{array}$ & $\begin{array}{l}-2.00 \\
(0.05)\end{array}$ & $\begin{array}{l}-2.00 \\
(0.05)\end{array}$ & 0 & 4 \\
\hline ARMA & $\begin{array}{c}1.94 \\
(0.05)\end{array}$ & & $\begin{array}{l}-0.21 \\
(0.83)\end{array}$ & $\begin{array}{l}-1.32 \\
(0.19)\end{array}$ & $\begin{array}{l}-1.33 \\
(0.18)\end{array}$ & 1 & 0 \\
\hline VAR & $\begin{array}{c}1.94 \\
(0.05)\end{array}$ & $\begin{array}{c}0.21 \\
(0.83)\end{array}$ & & $\begin{array}{l}-1.27 \\
(0.21)\end{array}$ & $\begin{array}{l}-1.27 \\
(0.20)\end{array}$ & 1 & 0 \\
\hline ARFIMA & $\begin{array}{c}2.00 \\
(0.05)\end{array}$ & $\begin{array}{c}1.32 \\
(0.19)\end{array}$ & $\begin{array}{c}1.27 \\
(0.21)\end{array}$ & & $\begin{array}{l}-0.97 \\
(0.33)\end{array}$ & 1 & 0 \\
\hline \multirow[t]{2}{*}{ VARFIMA } & $\begin{array}{c}2.00 \\
(0.05)\end{array}$ & $\begin{array}{c}1.33 \\
(0.18)\end{array}$ & $\begin{array}{c}1.27 \\
(0.20)\end{array}$ & $\begin{array}{c}0.97 \\
(0.33)\end{array}$ & & 1 & 0 \\
\hline & & & $h=9$ & & & & \\
\hline RW & & $\begin{array}{c}-1.94 \\
(0.05)\end{array}$ & $\begin{array}{l}-1.97 \\
(0.05)\end{array}$ & $\begin{array}{l}-2.13 \\
(0.03)\end{array}$ & $\begin{array}{l}-2.13 \\
(0.03)\end{array}$ & 0 & 4 \\
\hline ARMA & $\begin{array}{c}1.94 \\
(0.05)\end{array}$ & & $\begin{array}{l}-1.44 \\
(0.15)\end{array}$ & $\begin{array}{l}-1.32 \\
(0.19)\end{array}$ & $\begin{array}{l}-1.32 \\
(0.19)\end{array}$ & 1 & 0 \\
\hline VAR & $\begin{array}{c}1.97 \\
(0.05)\end{array}$ & $\begin{array}{c}1.44 \\
(0.15)\end{array}$ & & $\begin{array}{l}-1.20 \\
(0.23)\end{array}$ & $\begin{array}{l}-1.20 \\
(0.23)\end{array}$ & 1 & 0 \\
\hline ARFIMA & $\begin{array}{c}2.13 \\
(0.03)\end{array}$ & $\begin{array}{c}1.32 \\
(0.19)\end{array}$ & $\begin{array}{c}1.20 \\
(0.23)\end{array}$ & & $\begin{array}{c}0.95 \\
(0.34)\end{array}$ & 1 & 0 \\
\hline VARFIMA & $\begin{array}{c}2.13 \\
(0.03)\end{array}$ & $\begin{array}{c}1.32 \\
(0.19)\end{array}$ & $\begin{array}{c}1.20 \\
(0.23)\end{array}$ & $\begin{array}{l}-0.95 \\
(0.34)\end{array}$ & & 1 & 0 \\
\hline
\end{tabular}

Notes: Numbers in brackets represent the two-sided p-value for the modified DM test. A positive sign indicates that the forecast error of the row model is smaller than the column model. The last two columns indicate the number of times the row model significantly outperforms the column model $(+)$, or is outperformed $(-1)$. 
Table 3: Diebold-Mariano Tests with Boom Weighted Forecast Errors

\begin{tabular}{|c|c|c|c|c|c|c|c|}
\hline & RW & ARMA & VAR & ARFIMA & VARFIMA & plus & minus \\
\hline & & & $h=1$ & & & & \\
\hline RW & & $\begin{array}{l}-2.15 \\
(0.03)\end{array}$ & $\begin{array}{l}-1.66 \\
(0.10)\end{array}$ & $\begin{array}{l}-1.75 \\
(0.08)\end{array}$ & $\begin{array}{l}-1.99 \\
(0.05)\end{array}$ & 0 & 4 \\
\hline ARMA & $\begin{array}{c}2.15 \\
(0.03)\end{array}$ & & $\begin{array}{c}1.98 \\
(0.05)\end{array}$ & $\begin{array}{c}1.48 \\
(0.14)\end{array}$ & $\begin{array}{c}1.61 \\
(0.11)\end{array}$ & 2 & 0 \\
\hline VAR & $\begin{array}{c}1.66 \\
(0.10)\end{array}$ & $\begin{array}{c}-1.98 \\
(0.05)\end{array}$ & & $\begin{array}{l}-1.11 \\
(0.27)\end{array}$ & $\begin{array}{l}-1.48 \\
(0.14)\end{array}$ & 1 & 1 \\
\hline ARFIMA & $\begin{array}{c}1.75 \\
(0.08)\end{array}$ & $\begin{array}{c}-1.48 \\
(0.14)\end{array}$ & $\begin{array}{c}1.11 \\
(0.27)\end{array}$ & & $\begin{array}{l}-0.72 \\
(0.47)\end{array}$ & 1 & 0 \\
\hline \multirow[t]{2}{*}{ VARFIMA } & $\begin{array}{c}1.99 \\
(0.05)\end{array}$ & $\begin{array}{c}-1.61 \\
(0.11)\end{array}$ & $\begin{array}{c}1.48 \\
(0.14)\end{array}$ & $\begin{array}{c}0.72 \\
(0.47)\end{array}$ & & 1 & 0 \\
\hline & & & $h=3$ & & & & \\
\hline RW & & $\begin{array}{c}-2.00 \\
(0.05)\end{array}$ & $\begin{array}{l}-1.86 \\
(0.06)\end{array}$ & $\begin{array}{l}-2.01 \\
(0.04)\end{array}$ & $\begin{array}{l}-2.03 \\
(0.04)\end{array}$ & 0 & 4 \\
\hline ARMA & $\begin{array}{c}2.00 \\
(0.05)\end{array}$ & & $\begin{array}{c}2.57 \\
(0.01)\end{array}$ & $\begin{array}{l}-0.20 \\
(0.84)\end{array}$ & $\begin{array}{l}-0.63 \\
(0.53)\end{array}$ & 2 & 0 \\
\hline VAR & $\begin{array}{c}1.86 \\
(0.06)\end{array}$ & $\begin{array}{c}-2.57 \\
(0.01)\end{array}$ & & $\begin{array}{c}-2.96 \\
(<0.01)\end{array}$ & $\begin{array}{c}-3.09 \\
(<0.01)\end{array}$ & 1 & 3 \\
\hline ARFIMA & $\begin{array}{c}2.01 \\
(0.04)\end{array}$ & $\begin{array}{c}0.20 \\
(0.84)\end{array}$ & $\begin{array}{c}2.96 \\
(<0.01)\end{array}$ & & $\begin{array}{l}-1.51 \\
(0.13)\end{array}$ & 2 & 0 \\
\hline \multirow[t]{2}{*}{ VARFIMA } & $\begin{array}{c}2.03 \\
(0.04) \\
\end{array}$ & $\begin{array}{c}0.63 \\
(0.53) \\
\end{array}$ & $\begin{array}{c}3.09 \\
(<0.01) \\
\end{array}$ & $\begin{array}{c}1.51 \\
(0.13) \\
\end{array}$ & & 2 & 0 \\
\hline & & & $h=6$ & & & & \\
\hline RW & & $\begin{array}{c}-1.55 \\
(0.12)\end{array}$ & $\begin{array}{l}-1.53 \\
(0.13)\end{array}$ & $\begin{array}{l}-1.59 \\
(0.11)\end{array}$ & $\begin{array}{l}-1.59 \\
(0.11)\end{array}$ & 0 & 0 \\
\hline ARMA & $\begin{array}{c}1.55 \\
(0.12)\end{array}$ & & $\begin{array}{c}1.59 \\
(0.11)\end{array}$ & $\begin{array}{c}0.10 \\
(0.92)\end{array}$ & $\begin{array}{l}-0.00 \\
(1.00)\end{array}$ & 0 & 0 \\
\hline VAR & $\begin{array}{c}1.53 \\
(0.13)\end{array}$ & $\begin{array}{c}-1.59 \\
(0.11)\end{array}$ & & $\begin{array}{l}-0.72 \\
(0.47)\end{array}$ & $\begin{array}{l}-0.80 \\
(0.42)\end{array}$ & 0 & 0 \\
\hline ARFIMA & $\begin{array}{c}1.59 \\
(0.11)\end{array}$ & $\begin{array}{c}-0.10 \\
(0.92)\end{array}$ & $\begin{array}{c}0.72 \\
(0.47)\end{array}$ & & $\begin{array}{l}-2.15 \\
(0.03)\end{array}$ & 0 & 1 \\
\hline \multirow[t]{2}{*}{ VARFIMA } & $\begin{array}{c}1.59 \\
(0.11)\end{array}$ & $\begin{array}{c}0.00 \\
(1.00)\end{array}$ & $\begin{array}{c}0.80 \\
(0.42)\end{array}$ & $\begin{array}{c}2.15 \\
(0.03)\end{array}$ & & 1 & 0 \\
\hline & & & $h=9$ & & & & \\
\hline RW & & $\begin{array}{c}-1.58 \\
(0.11)\end{array}$ & $\begin{array}{l}-1.58 \\
(0.11)\end{array}$ & $\begin{array}{l}-1.61 \\
(0.11)\end{array}$ & $\begin{array}{l}-1.62 \\
(0.11)\end{array}$ & 0 & 0 \\
\hline ARMA & $\begin{array}{c}1.58 \\
(0.11)\end{array}$ & & $\begin{array}{c}1.05 \\
(0.29)\end{array}$ & $\begin{array}{l}-0.02 \\
(0.99)\end{array}$ & $\begin{array}{l}-0.07 \\
(0.95)\end{array}$ & 0 & 0 \\
\hline VAR & $\begin{array}{c}1.58 \\
(0.11)\end{array}$ & $\begin{array}{l}-1.05 \\
(0.29)\end{array}$ & & $\begin{array}{l}-0.23 \\
(0.82)\end{array}$ & $\begin{array}{l}-0.28 \\
(0.78)\end{array}$ & 0 & 0 \\
\hline ARFIMA & $\begin{array}{c}1.61 \\
(0.11)\end{array}$ & $\begin{array}{c}0.02 \\
(0.99)\end{array}$ & $\begin{array}{c}0.23 \\
(0.82)\end{array}$ & & $\begin{array}{c}-2.87 \\
(<0.01)\end{array}$ & 0 & 1 \\
\hline VARFIMA & $\begin{array}{c}1.62 \\
(0.11)\end{array}$ & $\begin{array}{c}0.07 \\
(0.95)\end{array}$ & $\begin{array}{c}0.28 \\
(0.78)\end{array}$ & $\begin{array}{c}2.87 \\
(<0.01)\end{array}$ & & 1 & 0 \\
\hline
\end{tabular}


Table 4: Diebold-Mariano Tests with Recession Weighted Forecast Errors

\begin{tabular}{|c|c|c|c|c|c|c|c|}
\hline & RW & ARMA & VAR & ARFIMA & VARFIMA & plus & minus \\
\hline & & & $h=1$ & & & & \\
\hline RW & & $\begin{array}{l}-0.65 \\
(0.51)\end{array}$ & $\begin{array}{c}-1.50 \\
(0.13)\end{array}$ & $\begin{array}{c}-0.56 \\
(0.58)\end{array}$ & $\begin{array}{c}-1.88 \\
(0.06)\end{array}$ & 0 & 1 \\
\hline ARMA & $\begin{array}{c}0.65 \\
(0.51)\end{array}$ & & $\begin{array}{c}-0.71 \\
(0.48)\end{array}$ & $\begin{array}{c}0.18 \\
(0.85)\end{array}$ & $\begin{array}{c}-0.99 \\
(0.32)\end{array}$ & 0 & 0 \\
\hline VAR & $\begin{array}{c}1.50 \\
(0.13)\end{array}$ & $\begin{array}{c}0.71 \\
(0.48)\end{array}$ & & $\begin{array}{c}0.63 \\
(0.53)\end{array}$ & $\begin{array}{c}-0.86 \\
(0.39)\end{array}$ & 0 & 0 \\
\hline ARFIMA & $\begin{array}{c}0.56 \\
(0.58)\end{array}$ & $\begin{array}{c}-0.18 \\
(0.85)\end{array}$ & $\begin{array}{c}-0.63 \\
(0.53)\end{array}$ & & $\begin{array}{c}-0.87 \\
(0.38)\end{array}$ & 0 & 0 \\
\hline VARFIMA & $\begin{array}{c}1.88 \\
(0.06) \\
\end{array}$ & $\begin{array}{c}0.99 \\
(0.32) \\
\end{array}$ & $\begin{array}{c}0.86 \\
(0.39) \\
\end{array}$ & $\begin{array}{c}0.87 \\
(0.38) \\
\end{array}$ & & 1 & 0 \\
\hline & & & $h=3$ & & & & \\
\hline RW & & $\begin{array}{l}-2.25 \\
(0.02)\end{array}$ & $\begin{array}{c}-2.54 \\
(0.01)\end{array}$ & $\begin{array}{c}-2.55 \\
(0.01)\end{array}$ & $\begin{array}{c}-2.53 \\
(0.01)\end{array}$ & 0 & 4 \\
\hline ARMA & $\begin{array}{c}2.25 \\
(0.02)\end{array}$ & & $\begin{array}{c}-1.54 \\
(0.12)\end{array}$ & $\begin{array}{c}-1.58 \\
(0.11)\end{array}$ & $\begin{array}{l}-1.35 \\
(0.18)\end{array}$ & 1 & 0 \\
\hline VAR & $\begin{array}{c}2.54 \\
(0.01)\end{array}$ & $\begin{array}{c}1.54 \\
(0.12)\end{array}$ & & $\begin{array}{c}-0.85 \\
(0.40)\end{array}$ & $\begin{array}{c}1.14 \\
(0.25)\end{array}$ & 1 & 0 \\
\hline ARFIMA & $\begin{array}{c}2.55 \\
(0.01)\end{array}$ & $\begin{array}{c}1.58 \\
(0.11)\end{array}$ & $\begin{array}{c}0.85 \\
(0.40)\end{array}$ & & $\begin{array}{c}1.22 \\
(0.22)\end{array}$ & 1 & 0 \\
\hline VARFIMA & $\begin{array}{c}2.53 \\
(0.01) \\
\end{array}$ & $\begin{array}{c}1.35 \\
(0.18)\end{array}$ & $\begin{array}{c}-1.14 \\
(0.25)\end{array}$ & $\begin{array}{l}-1.22 \\
(0.22)\end{array}$ & & 1 & 0 \\
\hline & & & $h=6$ & & & & \\
\hline RW & & $\begin{array}{c}-1.84 \\
(0.07)\end{array}$ & $\begin{array}{c}-1.81 \\
(0.07)\end{array}$ & $\begin{array}{c}-1.81 \\
(0.07)\end{array}$ & $\begin{array}{c}-1.89 \\
(0.06)\end{array}$ & 0 & 4 \\
\hline ARMA & $\begin{array}{c}1.84 \\
(0.07)\end{array}$ & & $\begin{array}{c}-1.31 \\
(0.19)\end{array}$ & $\begin{array}{c}-1.29 \\
(0.20)\end{array}$ & $\begin{array}{l}-1.98 \\
(0.05)\end{array}$ & 1 & 1 \\
\hline VAR & $\begin{array}{c}1.81 \\
(0.07)\end{array}$ & $\begin{array}{c}1.31 \\
(0.19)\end{array}$ & & $\begin{array}{c}1.65 \\
(0.10)\end{array}$ & $\begin{array}{c}1.06 \\
(0.29)\end{array}$ & 2 & 0 \\
\hline ARFIMA & $\begin{array}{c}1.81 \\
(0.07)\end{array}$ & $\begin{array}{c}1.29 \\
(0.20)\end{array}$ & $\begin{array}{c}-1.65 \\
(0.10)\end{array}$ & & $\begin{array}{c}1.05 \\
(0.30)\end{array}$ & 1 & 1 \\
\hline VARFIMA & $\begin{array}{c}1.89 \\
(0.06) \\
\end{array}$ & $\begin{array}{c}1.98 \\
(0.05)\end{array}$ & $\begin{array}{c}-1.06 \\
(0.29)\end{array}$ & $\begin{array}{l}-1.05 \\
(0.30)\end{array}$ & & 2 & 0 \\
\hline & & & $h=9$ & & & & \\
\hline RW & & $\begin{array}{c}-2.23 \\
(0.03)\end{array}$ & $\begin{array}{c}-2.39 \\
(0.02)\end{array}$ & $\begin{array}{l}-2.38 \\
(0.02)\end{array}$ & $\begin{array}{l}-2.30 \\
(0.02)\end{array}$ & 0 & 4 \\
\hline ARMA & $\begin{array}{c}2.23 \\
(0.03)\end{array}$ & & $\begin{array}{c}-1.28 \\
(0.20)\end{array}$ & $\begin{array}{c}-1.27 \\
(0.21)\end{array}$ & $\begin{array}{c}-2.42 \\
(0.02)\end{array}$ & 1 & 1 \\
\hline VAR & $\begin{array}{c}2.39 \\
(0.02)\end{array}$ & $\begin{array}{c}1.28 \\
(0.20)\end{array}$ & & $\begin{array}{c}2.42 \\
(0.02)\end{array}$ & $\begin{array}{c}1.11 \\
(0.27)\end{array}$ & 2 & 0 \\
\hline ARFIMA & $\begin{array}{c}2.38 \\
(0.02)\end{array}$ & $\begin{array}{c}1.27 \\
(0.21)\end{array}$ & $\begin{array}{c}-2.42 \\
(0.02)\end{array}$ & & $\begin{array}{c}1.10 \\
(0.27)\end{array}$ & 1 & 1 \\
\hline VARFIMA & $\begin{array}{c}2.30 \\
(0.02)\end{array}$ & $\begin{array}{c}2.42 \\
(0.02)\end{array}$ & $\begin{array}{c}-1.11 \\
(0.27)\end{array}$ & $\begin{array}{l}-1.10 \\
(0.27)\end{array}$ & & 2 & 0 \\
\hline
\end{tabular}


Table 5: Diebold-Mariano Tests with Tail Weighted Forecast Errors

\begin{tabular}{|c|c|c|c|c|c|c|c|}
\hline & RW & ARMA & VAR & ARFIMA & VARFIMA & plus & minus \\
\hline & & & $h=1$ & & & & \\
\hline RW & & $\begin{array}{c}0.10 \\
(0.92)\end{array}$ & $\begin{array}{c}-0.83 \\
(0.41)\end{array}$ & $\begin{array}{l}-0.68 \\
(0.49)\end{array}$ & $\begin{array}{c}0.20 \\
(0.84)\end{array}$ & 0 & 0 \\
\hline ARMA & $\begin{array}{c}-0.10 \\
(0.92)\end{array}$ & & $\begin{array}{c}-0.77 \\
(0.44)\end{array}$ & $\begin{array}{c}-0.85 \\
(0.39)\end{array}$ & $\begin{array}{c}0.92 \\
(0.36)\end{array}$ & 0 & 0 \\
\hline VAR & $\begin{array}{c}0.83 \\
(0.41)\end{array}$ & $\begin{array}{c}0.77 \\
(0.44)\end{array}$ & & $\begin{array}{c}0.15 \\
(0.88)\end{array}$ & $\begin{array}{c}0.81 \\
(0.42)\end{array}$ & 0 & 0 \\
\hline ARFIMA & $\begin{array}{c}0.68 \\
(0.49)\end{array}$ & $\begin{array}{c}0.85 \\
(0.39)\end{array}$ & $\begin{array}{c}-0.15 \\
(0.88)\end{array}$ & & $\begin{array}{c}0.89 \\
(0.38)\end{array}$ & 0 & 0 \\
\hline \multirow[t]{2}{*}{ VARFIMA } & $\begin{array}{c}-0.20 \\
(0.84)\end{array}$ & $\begin{array}{c}-0.92 \\
(0.36)\end{array}$ & $\begin{array}{c}-0.81 \\
(0.42)\end{array}$ & $\begin{array}{c}-0.89 \\
(0.38)\end{array}$ & & 0 & 0 \\
\hline & & & $h=3$ & & & & \\
\hline RW & & $\begin{array}{c}-2.03 \\
(0.04)\end{array}$ & $\begin{array}{c}-2.21 \\
(0.03)\end{array}$ & $\begin{array}{l}-2.42 \\
(0.02)\end{array}$ & $\begin{array}{l}-2.44 \\
(0.01)\end{array}$ & 0 & 4 \\
\hline ARMA & $\begin{array}{c}2.03 \\
(0.04)\end{array}$ & & $\begin{array}{c}-0.28 \\
(0.78)\end{array}$ & $\begin{array}{l}-1.33 \\
(0.18)\end{array}$ & $\begin{array}{l}-1.42 \\
(0.16)\end{array}$ & 1 & 0 \\
\hline VAR & $\begin{array}{c}2.21 \\
(0.03)\end{array}$ & $\begin{array}{c}0.28 \\
(0.78)\end{array}$ & & $\begin{array}{l}-1.94 \\
(0.05)\end{array}$ & $\begin{array}{l}-2.08 \\
(0.04)\end{array}$ & 1 & 2 \\
\hline ARFIMA & $\begin{array}{c}2.42 \\
(0.02)\end{array}$ & $\begin{array}{c}1.33 \\
(0.18)\end{array}$ & $\begin{array}{c}1.94 \\
(0.05)\end{array}$ & & $\begin{array}{l}-1.35 \\
(0.18)\end{array}$ & 2 & 0 \\
\hline \multirow[t]{2}{*}{ VARFIMA } & $\begin{array}{c}2.44 \\
(0.01)\end{array}$ & $\begin{array}{c}1.42 \\
(0.16)\end{array}$ & $\begin{array}{c}2.08 \\
(0.04)\end{array}$ & $\begin{array}{c}1.35 \\
(0.18)\end{array}$ & & 2 & 0 \\
\hline & & & $h=6$ & & & & \\
\hline RW & & $\begin{array}{c}-1.65 \\
(0.10)\end{array}$ & $\begin{array}{c}-1.66 \\
(0.10)\end{array}$ & $\begin{array}{l}-1.63 \\
(0.10)\end{array}$ & $\begin{array}{l}-1.64 \\
(0.10)\end{array}$ & 0 & 2 \\
\hline ARMA & $\begin{array}{c}1.65 \\
(0.10)\end{array}$ & & $\begin{array}{c}-0.11 \\
(0.91)\end{array}$ & $\begin{array}{l}-1.15 \\
(0.25)\end{array}$ & $\begin{array}{l}-1.17 \\
(0.24)\end{array}$ & 1 & 0 \\
\hline VAR & $\begin{array}{c}1.66 \\
(0.10)\end{array}$ & $\begin{array}{c}0.11 \\
(0.91)\end{array}$ & & $\begin{array}{l}-1.13 \\
(0.26)\end{array}$ & $\begin{array}{c}-1.14 \\
(0.25)\end{array}$ & 1 & 0 \\
\hline ARFIMA & $\begin{array}{c}1.63 \\
(0.10)\end{array}$ & $\begin{array}{c}1.15 \\
(0.25)\end{array}$ & $\begin{array}{c}1.13 \\
(0.26)\end{array}$ & & $\begin{array}{l}-1.41 \\
(0.16)\end{array}$ & 0 & 0 \\
\hline \multirow[t]{2}{*}{ VARFIMA } & $\begin{array}{c}1.64 \\
(0.10)\end{array}$ & $\begin{array}{c}1.17 \\
(0.24)\end{array}$ & $\begin{array}{c}1.14 \\
(0.25)\end{array}$ & $\begin{array}{c}1.41 \\
(0.16)\end{array}$ & & 0 & 0 \\
\hline & & & $h=9$ & & & & \\
\hline RW & & $\begin{array}{c}-1.98 \\
(0.05)\end{array}$ & $\begin{array}{c}-2.05 \\
(0.04)\end{array}$ & $\begin{array}{l}-2.08 \\
(0.04)\end{array}$ & $\begin{array}{l}-2.08 \\
(0.04)\end{array}$ & 0 & 4 \\
\hline ARMA & $\begin{array}{c}1.98 \\
(0.05)\end{array}$ & & $\begin{array}{c}-1.35 \\
(0.18)\end{array}$ & $\begin{array}{l}-1.14 \\
(0.26)\end{array}$ & $\begin{array}{l}-1.14 \\
(0.26)\end{array}$ & 1 & 0 \\
\hline VAR & $\begin{array}{c}2.05 \\
(0.04)\end{array}$ & $\begin{array}{c}1.35 \\
(0.18)\end{array}$ & & $\begin{array}{l}-1.07 \\
(0.29)\end{array}$ & $\begin{array}{l}-1.07 \\
(0.29)\end{array}$ & 1 & 0 \\
\hline ARFIMA & $\begin{array}{c}2.08 \\
(0.04)\end{array}$ & $\begin{array}{c}1.14 \\
(0.26)\end{array}$ & $\begin{array}{c}1.07 \\
(0.29)\end{array}$ & & $\begin{array}{c}0.92 \\
(0.36)\end{array}$ & 1 & 0 \\
\hline VARFIMA & $\begin{array}{c}2.08 \\
(0.04)\end{array}$ & $\begin{array}{c}1.14 \\
(0.26)\end{array}$ & $\begin{array}{c}1.07 \\
(0.29)\end{array}$ & $\begin{array}{l}-0.92 \\
(0.36)\end{array}$ & & 1 & 0 \\
\hline
\end{tabular}


Table 6: Model performance over all periods - counts of statistical significance

\begin{tabular}{lrrr}
\hline & Total + & Total - & Score \\
\hline RW & Uniform & & \\
ARMA & 0 & 46 & -46 \\
VAR & 11 & 4 & 7 \\
ARFIMA & 14 & 2 & 12 \\
VARFIMA & 13 & 0 & 13 \\
\hline & 14 & 0 & 14 \\
RW & & & \\
ARMA & Boom & & \\
VAR & 0 & 27 & -27 \\
ARFIMA & 13 & 0 & 13 \\
VARFIMA & 6 & 10 & -4 \\
\hline & 9 & 7 & 2 \\
RW & 16 & 0 & 16 \\
ARMA & Recession & & \\
VAR & 0 & 41 & -41 \\
ARFIMA & 9 & 9 & 0 \\
VARFIMA & 17 & 0 & 17 \\
\hline & 11 & 7 & 4 \\
RW & 20 & 0 & 20 \\
ARMA & Tail & & \\
VAR & 0 & 20 & -20 \\
ARFIMA & 5 & 2 & 3 \\
VARFIMA & 7 & 2 & 5 \\
\hline & 6 & 0 & 6 \\
& 6 & 0 & 6 \\
\hline
\end{tabular}

Notes: Scores are summed over 12 forecast horizons

competing models are from a policy perspective? Since inflation is likely to have real economic effects, knowing what moves inflation, how persistent is inflation and what inflation is likely to be in the near future is of great importance to Central Banks that have inflation as a main target. A better forecasting model may help Central Bankers to improve the timing of their policy decisions as well as the extent of the policy decisions.

\section{Conclusion}

We compare the forecasting performance of a VARFIMA model against a number of traditional inflation forecasting models. Augmenting U.S. inflation data with a policy uncertainty variable improves the forecasting performance over simple univariate and multivariate specifications. Exploiting the information that inflation is a near unit root in a fractionally integrated framework further improves inflation forecasting. Our results show that the VARFIMA model has the lowest RMSE and is not statistically outperformed by other inflation forecasts 
specifications - these results are supported when penalizing forecast evaluation during booms and recessions.

\section{References}

Ashley, R. "A new technique for postsample model selection and validation", Journal of Economic Dynamics and Control. 22(5), 1998, 647-665.

Aye, G. C.; Balcilar, M.; Gupta R., and Majumdar A. "Forecasting aggregate retail sales: the case of South Africa", International Journal of Production Economics. 160(1), 2015: 66-79.

Bai, J., and Perron, P. "Computation and analysis of multiple structural change models", Journal of Applied Econometrics. 18(1), 2003: 1-22.

Baker, S.; Bloom, N., and Davis, S. Measuring economic policy uncertainty. Working Paper 2013, Stanford University.

Barros, C. P., and Gil-Alana, L. A. "Inflation forecasting in Angola: a fractional approach", African Development Review. 25(1), 2013: 91-104.

Bloom, N. "The Impact of Uncertainty Shocks", Econometrica, 77(3), 2009, 623-685.

Caporin, M., and Gupta, R. Time-varying persistence in US inflation. Empirical Economics, Forthcoming.

Colombo, V. "Economic policy uncertainty in the US: Does it matter for the Euro Area?" Economics Letters. 121(1), 2013: 39-42.

Diebold F X., and Mariano R S. "Comparing Predictive Accuracy", Journal of Business and Economic Statistics. 13(3), 1995: 253-263.

Faust, J., and Wright, J.H. "Inflation forecasting", Handbook of forecasting. 2, 2-56. Available from: http://www.econ2.jhu.edu/People/Wright/inf_forecast.pdf. [Accessed: 6 September 2014].

Hassler U. "(Mis)specification of long memory in seasonal time series", Journal of Time Series Analysis. 14 (1), 1994: 19-30.

Harvey, D. I.; Leybourne, S., and Newbold, P. "Testing the Equality of Prediction Mean Squared Errors", International Journal of Forecasting. 13, 1997: 281-291.

Jones, P.M., and Olson, E. "The time-varying correlation between uncertainty, output and inflation: Evidence from a DCC-GARCH model", Economic Letters. 118 (2013), 2013: 33-37.

Lovcha, Y., and Perez-Laborda, A, P. A fractionally integrated approach to monetary policy and inflation dynamics. Centre de Recerca en Economia Industrial I Economia Publica WP 02-2013, 2013.

Makridakis, S., and Hibbon, M. "The M-3 Competition: results, conclusions and implications", International Journal of Forecasting. 16 (2000), 2000: 451-476.

Mumtaz, H., and Zanetti, F. "The impact of monetary policy shocks", Journal of Money, Credit and Banking, vol. 45, 2013: 535-558. 
Ravishanker, R., and Ray, B.K. "Bayesian prediction for vector ARFIMA processes", International Journal of Forecasting. 18(2002), 2002: 207-214.

Stock, J.H., and Watson, M.W. Phillips curve inflation forecasts, in "Understanding inflation and the implications for monetary policy", Jeffrey Fuhrer, Yolanda Kodrzycki, Jane Little and Giovanni Olivei (eds.), MIT Press, Cambride, 2009.

Van Dijk, D., and Franses, P. H. "Selecting a Non-linear Time-series Model Using Weighted Tests of Equal Forecast Accuracy", Oxford Bulletin of Economics and Statistics. 65, 2003: 727-744. 